\title{
MOSCOW-CYPRUS RELATIONS SINCE THE 1950S: A SCHEMATIC INTRODUCTION
}

\author{
Costas Melakopides ${ }^{*}$
}

DOI 10.24833/2073-8420-2019-4-53-39-55

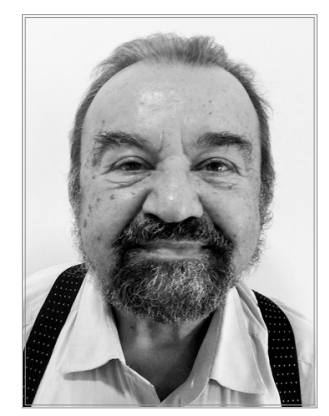

Allowing for inevitable disagreements, stemming from political, ideological, psychological propensities and fixed ideas, it should be undeniable that, throughout the post-World War II era, Moscow had displayed friendship, solidarity and multidimensional support towards Cyprus and its overwhelming Greek Cypriot majority. Hence the recurrent expressions of "gratitude" by Cypriot political elites, opinion makers, and large sectors of civil society. Three primary sources of this "special relationship" stand out: first, Moscow, while serving its own geopolitical goals, simultaneously offered Cyprus protection against Anglo-American errors, sins and even crimes; second, in contrast to the West's exclusively self-regarding strategies and tactics towards $C y$ prus, the Moscow-Cyprus bilateral bonding has overall been premised on a synthesis of mutual interests, shared norms and common values; and third, until very recently, Moscow extended to the Republic of Cyprus sustained understanding and support regarding Turkey's threats and provocations. Except for the last dimension - addressed near the end of this essay - my major theses and supporting empirical evidence regarding the sui generis Russia-Cyprus relationship were first developed in my 2016 book, Russia-Cyprus Relations ${ }^{1}$.

\section{Introduction}

1 $\mathrm{s}$ an "unsinkable aircraft carrier" in the Eastern Mediterranean, Cyprus inevitably became a Cold War apple of discord, since Soviet Moscow, in tandem with the West, aspired to satisfy via Cyprus various geostrategic goals. Although, whereas nearly all relevant analyses are confined to narrow Realpolitik readings, my insertion of "idealist" norms and values became necessary in order to reflect the important idiosyncrasies of Moscow-Cyprus relations: that is, religious, historical, political, cul- tural, and psychological affinities and bonds as well as respect for international legal and ethical principles and norms.

Now given that Cyprus' (quasi)-independence from British Colonialism was won through a painful national liberation struggle (1955-1959); and that a Constitution externally imposed - by the US, the UK and NATO - blatantly favoured the Turkish Cypriot minority (as a service to Turkey), the Greek Cypriot majority $(80 \%)$ nurtured deep discontent and anger towards Washington and London. Unsurprisingly, most Greeks of Cyprus turned favourably to Moscow.

\footnotetext{
* Costas Melakopides, Associate Professor of International Relations (ret.), University of Cyprus e-mail: comel@ucy.ac.cy ORCID ID: 0000-0001-9968-1931
}

\footnotetext{
1 See Costas Melakopides, Russia-Cyprus Relations: A Pragmatic Idealist Perspective (London: Palgrave, 2016). (For reasons of space, the present essay will frequently appeal to this book.)The term "Pragmatic Idealism" was introduced to International Relations Theory in my 1998 book Pragmatic Idealism: Canadian Foreign Policy, 19451995 (McGill-Queen's University Press).
} 
These sentiments were progressively strengthened until 1991, thanks to additional sins and crimes committed against Cyprus by Washington, Ankara and London (to be recalled below). With the Cold War's end, Russo-Cypriot bonding flourished even further, accumulating thereby rich mutual benefits. "Pragmatic Idealism" is my proposed term especially for their bilateral relations for 20 years after $1992{ }^{2}$

Arguably, however, tentative changes could be perceived since the mid-2010s, when affirmations of pragmatic idealism by both sides could not be unaffected by the Eastern Mediterranean geopolitical adventures. Primarily, they comprise the ever deepening Russia-Turkey rapprochement; the renewed manifold US-Russia antagonism; Cyprus' discovery of rich hydrocarbon deposits in its Exclusive Economic Zone (EEZ); and Turkey's intensified anti-Hellenic bellicosity on top of the unending, since the 1974 invasion, illegal occupation of $37 \%$ of Cypriot territory.

This essay, then, will first address the extended positive periods of their relations, before turning to today's geopolitical fluidity. Here, President Erdogan's regional troublemaking and heightened anti-Cyprus and anti-Greece aggression have complicated Russia-Cyprus relations both indirectly and immediately. Put succinctly, while unwilling to "abandon" Cyprus, Moscow today hesitates to contain Ankara's anti-Cyprus (and anti-Greece) escalating hostility. Evidently, the resulting relative indeterminacy needs to be explored.

Methodologically, my approach opposes "Political Realism", contradicting thereby its inherently cynical perception of Moscow's Cyprus policies. Hence this essay may annoy the aficionados of Realpolitik and surprise those untutored in the rich empirical record supporting a Pragmatic Idealist analysis. To repeat, my analysis clearly acknowledges Russia's self-regarding geopolitical interests, especially during the Cold War. But only a normative method could reveal such "idealist" dimensions as the international legal and ethical values and norms, as well as Russian-Cypriot political, religious, cultural and "spiritual" affinities and bonds. Moreover, only a normative approach could judge the culprits of Cyprus' repeated victimisation, by openly criticising London, Washington and Ankara, but frequently also Cyprus' own elites. Therefore, I share British author Christopher Hitchens' conviction that 'acquiescence in injustice is not 'realism'. Once the injustice has been set down and described, and called by its right name, acquiescence in it becomes impossible. That is why one writes about Cyprus in sorrow but more -much more- in anger.' ${ }^{3}$.

\section{Moscow-Cyprus relations until 1991}

With the Cold War underway, Moscow's geopolitical interest in Cyprus preceded the Republic of Cyprus' establishment in 1960. Indeed, Moscow explicitly supported Cyprus' Greek Cypriot (GC) majority in the UN General Assembly when, inspired by the December 1952 Resolution on self-determination, the GCs asked Athens to represent them at the UN. However, despite the global decolonisation momentum and the monumental Greek sacrifices during the World War II, London adamantly refused to liberate Cyprus. Assisted by Washington, whose "containment" of the USSR was at new heights, the General Assembly's 1954 agenda excluded the Cypriot request. Besides the UK and the US, three more NATO members voted against the Greek appeal. In contrast, the USSR voted in favour of the Cypriots.

Establishing the Republic of Cyprus. Consequently, the GCs resorted to an anti-colonial struggle. The UK, deepening divide-and-rule, favoured the Turkish Cypriots (TCs) in scandalous ways. As William Mallinson has written, "at a time when all Greek-speaking political parties were banned, the British authorities allowed the Turkish Cypriots to establish a political party called 'Cyprus is Turkish'. Although many members of EOKA were hanged and imprisoned, very few members of Volkan, a Turkish Cypriot terrorist group, were even tried.' ". ."

Similarly, Vassilis Fouskas noted: "Britain, facing the Greek Cypriots' ferocious anti-colonial uprising, pitted the Turks against the Greeks by setting up auxiliary police totally composed of Turkish Cypriots [who] tortured Greek Cypriots under the blissful eye of British lieutenants $^{\prime 5}$.

On London's ruthlessness, that guaranteed the GCs' alienation from the UK, Perry Anderson added the following in the London Review of Books: ${ }^{6}$

\footnotetext{
2 For the period until 1991, I proposed "Latent Pragmatic Idealism" as more appropriate (see op.cit. chapter 4).

3 Christopher Hitchens, Hostage to History (London and New York: Verso, 1997), p. 166.

4 William Mallinson, Cyprus: A Modern History (London: I. B. Tauris, 2005), p.23.

5 Vassilis K. Fouskas and Alex O. Tackie, Cyprus: The Post-Imperial Constitution (London: Pluto Press, 2009), p.16.

6 Perry Anderson, "The Divisions of Cyprus", London Review of Books, Vol. 30, No 8, 24 April 2008, pp. 7-16, italics mine.
} 
"The standard repertoire of repression was applied. Makarios was deported. Demonstrations were banned, schools closed, trade-unions outlawed. Communists were locked up, EOKA suspects hanged. Curfews, raids, beatings, executions were the background against which, a year later, Cyprus supplied the air-deck for the Suez expedition".

EOKA's success seemed all but inevitable, considering "the breadth of support the national cause enjoyed among the population." And yet, the end of the struggle produced merely Cyprus' "quasi-liberation": for not only it inherited two "Sovereign British Bases" but also "independence agreements" that two Cyprus experts have called "fatally flawed"8.

"[They] established a system of government and security that was doomed from the start to promote divisions which eventually led to bloodshed. It had been devised by outside powers, bartering over their own political and defense interests on the island, and not by the people who had to live there, and resulted in neither real independence and unity nor a workable system of government."

The Republic of Cyprus was thus established with the "blessings" of London, Washington and NATO on 16 August 1960. Moscow recognised it two days later. The anticipated domestic instability erupted in December 1963. Turkey apparently engineered a domestic conflict that became a major international crisis. When President Makarios, was faced with crippling governmental malfunctioning, suggested constitutional improvements, TC extremists opted for rebellion. To contain it, the United Nations sent a Peacekeeping Force (UNFICYP) that remains on the Island ever since.

UN Security Council Resolution 186 of March 1964, establishing UNFICYP, is clearly historic. For it falsified Turkey's "official" narrative: that the TCs were "victimised" by the Greek majority, "expelled" from the Nicosia administration, and "forced" to hide in enclaves, because the Greeks had hijacked the newborn Republic.

Moscow was instrumental in the adoption of 186/1964. Former Cypriot Foreign Minister, Dr Erato Kozakou-Markoullis, had emphasised Moscow's decisive role. She recalled that "some countries reacted negatively" to the resolution, because the UNFICYP would be " "acting with the approval of the Government of the Republic of Cyprus".
\{But\} the Soviet Union stood by us and by this very important wording $\{\ldots\}$ the international community through the Security Council recognises the Government of Cyprus as representing the whole Republic of Cyprus and all the people of Cyprus. So Moscow's support was vital at a very critical moment". ${ }^{\prime \prime}$

Thus, the foundations of a "special relationship" were being constructed. Needless to say, Moscow's pro-Nicosia logic had two parallel sources: the "pragmatic" and the "idealist". The former, representing Realpolitik, included: Moscow's eagerness to prevent NATO hegemony over the Republic; the removal of the British bases from Cyprus if it could not be removed from the West; the cultivation of strong -ideological and political- ties with the fully pro-Soviet Cypriot communist party AKEL; and the desire to establish its credentials as a world power.

Such strategic considerations have dominated diachronically nearly all analyses of Russia-Cyprus relations. But although valid, they cannot suffice to explain Moscow's pro-Cyprus Cold War policies. By ostracising the normative dimension, they commit the fallacy of petitio principii or begging the question. For they exclude a priori and by an "authoritarian" fiat all value judgements about legal and ethical issues and all humane considerations, including solidarity and friendship.

Demonstrably, however, Moscow's pre-1992 Cyprus policy was motivated primarily, but not exclusively, by "realist" goals. "Pragmatic Idealism" is meant to capture precisely this crucial differentia specifica. The historical record includes Moscow's powerful declarations, decisions and actions in defense of Cyprus' rights and needs, whereas Washington and London aimed exclusively at submission to NATO. As the former Undersecretary of State, George Ball, confessed regarding the 1964 Cyprus crisis, ${ }^{10}$

"Viewed from Washington, the issue was clear enough. Cyprus was a strategically important piece of real estate at issue between two NATO partners: Greece and Turkey. We needed to keep it under NATO contro.l".

Two Antithetical Approaches. The US-UKNATO complex operated vis-à-vis Cyprus equally cynically throughout the Cold War. Inevitably, Cyprus suffered from their erroneous and often inhuman decisions, that included primarily: ${ }^{11}$ the toxic (secret) British nod of approval

\footnotetext{
7 Ibid., emphasis added.

8 Brendan O'Malley and Ian Craig, The Cyprus Conspiracy: America, Espionage and the Turkish Invasion (London: I. B. Tauris, 1999), p.78 (emphases added).

9 See Costas Melakopides, Russia-Cyprus Relations, op. cit., p.55.

10 George Ball, The Past Has Another Pattern (New York: Norton, 1982), p.342, emphases added.

${ }^{11}$ For rich bibliography, see Russia-Cyprus Relations, pp. 44-72.
} 
to Makarios' proposals to improve the constitution (that ignited the 1973 Turkish Cypriot rebellion); sustained machinations aiming at Cyprus' partition; the Washington-"inspired" 1967-1974 Colonels' dictatorship in Greece; the devious disregard of the Greek junta's preparations for the anti-Makarios coup; the implicit green light to the first Turkish invasion of July 1974; Henry Kissinger's demonstrable encouragement for the August 1974 second Turkish invasion; ${ }^{12}$ and the brutal violation of the Cypriots' human rights by the post-1974 Turkish occupation while pretending to help the UN "resolve" the Cyprus problem. This tragic list of acts and omissions could not but alienate utterly the Greeks of Cyprus from Washington and London.

Contrariwise, Moscow was entrenching its positive image because, while serving its aforementioned geopolitical goals, it also extended to Cyprus multiple protection and support. ${ }^{13}$ Characteristically, Moscow immediately supplied the Republic with military hardware desperately needed to handle Turkey's threats and provocations; the USSR also offered constant verbal solidarity, while Czechoslovakia and East Germany also provided various weapons systems; ${ }^{14}$ Nikita Khruschev repeatedly warned Turkey against its threatened invasions, beginning in summer 1964; Moscow consistently opposed the Western designs to partition Cyprus, ${ }^{15}$ systematically, it called for settling the Cyprus problem by an international conference according to international law, as against NATO's selfserving fixations; and it kept providing Cypriot youth with generous scholarships to study in Soviet universities.

Thus, by utilising the ample space provided by Western behavior, Moscow defended Cyprus' security interests and satisfied many of its political needs in accordance with legal norms, ethical values, and humane solidarity and care. Therefore, while accepting the predominance of Moscow's strategic interests during the Cold War, I have labelled "Latent Pragmatic Idealism" this synthesis of interests, principles and values that served Moscow's multiple goals and Cyprus' obvious needs.

To be sure, Moscow's "neutrality" during Turkey's 1974 invasion constitutes the realists' major attack against its Cyprus policies. Pragmatic Idealism, however, may reply as follows: first, that Moscow's (pragmatic) stance, far less than the West's, represented the realist canon's core; second, that while Pragmatic Idealism does acknowledge Moscow's "pragmatic" decisions, it is unique in recognising their synthesis with the "idealist" dimensions; and third, one wonders whether realists could possibly consider rational a potentially global conflict on behalf of Cyprus at the height of the Cold War! ${ }^{16}$

\section{Cyprus-Russia Relations, 1992-2012}

Since Moscow's geostrategic concerns decreased by the end of the Cold War, the new era encouraged the flourishing of the idealist dimensions. Traditionally characterising Moscow's relations with Hellenism in general, they included religious, cultural, linguistic, aesthetic, and, of course, historical and political affinities, ethical influences and ties, to be demonstrated below.

Typical Examples of Bilateral Affinities and Bonds. Most valuable are Ambassador Georgi L. Muradov's statements and judgements, collected in his Russia-Cyprus: Our Common Way ${ }^{17}$. The Russian diplomat celebrated various sentiments, ideas, values and bonds shared by Russians and Cypriots. Thus, when asked "whether Hellenism and the Russian people have additional connecting features besides religion", he replied:

"Certainly! I think they also have the same mentality, as peoples, but also the same ethical spirit. Of course, since times past, there is the economic, the political and the cultural connection. I am talking of the ancient years when the first Tsars or the princes were getting married to Greek women". 18

In June 1999, discussing whether the Greeks (of both Cyprus and Greece) appreciate and enjoy Russia's great cultural tradition, he stated:

"Both in Greece and in Cyprus, the Russian culture has great effect and impact. It is popular! In literature, in music, and the other arts. I realize this when I see the Russian folklore groups performing in Cyprus. They literally enjoy an apotheosis. And this proves that the connection

\footnotetext{
12 See, inter alia, William Mallinson's Kissinger and the Invasion of Cyprus: Diplomacy in the Eastern Mediterranean (Cambridge: Cambridge Scholars Publishing, 2016).

${ }^{13}$ See Russia-Cyprus Relations, pp.58-60.

${ }^{14}$ Andreas Stergiou, "Soviet Policy toward Cyprus", The Cyprus Review, Vol. 19, No2, Fall 2007, pp.121-128.

${ }^{15}$ See Russia-Cyprus Relations, p.57 for British Officer Martin Packard's eye-opening confessions.

${ }^{16}$ For a lengthy discussion, see Russia-Cyprus Relations, pp. 67-69.

${ }^{17}$ Georgi L. Muradov, Russia-Cyprus: Our Common Way (Nicosia: .S.Satellite Publication Ltd., 2000?).

${ }^{18}$ Ibid, p. 134.
} 
of our peoples has deep roots which go back in centuries". ${ }^{19}$

When the Cypriot interviewer noted the profound Hellenic gratitude for Russia's literary heritage, Muradov responded in characteristic idealist terms:

"Thank you very much. I believe that our two civilisations are very much interconnected. Mentality, tradition, Orthodoxy unite us as people very closely. And I must say that culture provides people with the same ethics, and I see that the evaluations, the values of Cypriots and Greeks, of Hellenism generally and of the Russians, are almost the same. I am talking about the values of today's world". ${ }^{20}$

Russian-Hellenic normative affinity is further demonstrated through international law. Besides Muradov's "pragmatic idealist" (i.e. legal and humanitarian) condemnation of Serbia's bombing by NATO, ${ }^{21}$ Argyrios Pisiotis has emphasised that Moscow, like Hellenism, favours legal solutions to international problems. Telling are the ratification of the Law of the Sea Convention and the Cyprus question. ${ }^{22}$ Moscow's "stated preference for a 'legal' solution to the bilateral problems that caused the Imia confrontation, ${ }^{23}$ was identical with Athens' position. By supporting international legal solutions to the Greek-Turkish disputes, Russia was not only opposing the Anglo-American preference for "political dialogue" between the two "NATO partners" -which manifestly favored Turkey- but was also contradicting Ankara's traditional stance, which arguably fears that international law stands against it whereas a "dialogue" might entail Greek concessions.

The Notorious S-300 Missiles. Security and defense retained an elevated place in Russia's Cyprus policies. The purchase of the Russian S-300 missiles for the Republic's air-defense also reflected "pragmatic idealism": serving legitimate Russian commercial interests in tandem with shared values, including Cyprus' honorable de- fense against the perennial Turkish threats.

For months then, Ankara had resorted to threats against Nicosia and intense lobbying against their installation. When Moscow signaled its decision to deliver the missiles, "Turkey threatened to strike the Russian vessels carrying the missiles to Cyprus. Moscow described the Turkish threats as an outright provocation and a casus belli" ${ }^{24}$ Ambassador Muradov stated to Turkey's Anadolou news agency that "if Turkey were to attack any ship carrying S-300 missiles to Cyprus via the Turkish Straits, this would be cause for war" 25 .

Moreover, besides repeating Moscow's casus belli threat, Georgi Muradov shared again the Cypriot -and international law- ${ }^{26}$ position on the essential nature of the Cyprus problem: "The current situation in Cyprus did not result from the deal to purchase the missiles but from the 1974 Turkish invasion and the continued occupation of the island's northern third"27.

In October 2014, then President of the Cypriot Parliament, Yiannakis Omirou, defended Moscow's principled and sustained support for Cyprus, through diplomatic, political and defense means. He also revealed that, as Minister of Defense, his Russian counterpart, Marshall Sergeef, had handed him in Moscow the following message from President Boris Yeltsin to Cypriot President Glafkos Clerides:

"We are ready to send two frigates to the Port of Limassol one week before the arrival of the missiles. The frigates will possess anti-air systems which will cover not only Cyprus but also the entire Mediterranean. Then we will see if the Turks would dare to attack" 28 .

Moscow's Historic 2004 UN Veto. Moscow's principled Cyprus policy was famously demonstrated anew by the April 2004 Russian UN Veto, the first such veto in ten years ${ }^{29}$. It took place just before the twin referenda on the "Annan plan". Secretary General, Kofi Annan, had been urging the Security Council to adopt a res-

\footnotetext{
19 Ibid., emphasis added.

${ }^{20}$ Ibid., p.123 (my translation).

${ }^{21}$ Muradov, op.cit., 25 April 1999, pp.115-116.

${ }^{22}$ Argyrios Pisiotis, "Greece and Turkey in the Concentric Circles of Russian Post-Cold War Foreign Policy", in Christodoulos Yialourides and Panayiotis Tsakonas (eds.), Greece and Turkey After the End of the Cold War (Athens: Caratzas, 2001), p.412.

${ }^{23}$ Ibid.

${ }^{24}$ Andreas Stergiou, "Les Russes a Chypre dans I'apres-Guerre froide", Outre-Terre: Revue europeenne de geopolique, Vol.27, 2001.p.125.

25 "Russia threatens retaliation over S-300 missiles", Hurriyet Daily News, 10 November 1997(accessed 24 October 2014).

${ }^{26}$ See Russia-Cyprus Relations, ch.2, entitled, "The Cyprus Problem, International Law, and the Annan Plan".

27 "Russia warns Turkey", Cyprus News Agency, 26 November 1997.

28 Yiannakis Omirou, "Russia's stance towards Cyprus and a revelation", Phileleftheros website, 29 October 2014.

${ }^{29}$ For details, see Russia-Cyprus Relations, pp.78-80.
} 
olution on proposed security arrangements for Cyprus should the Cypriots vote for "reunification". Given, however, the opinion polls' clear prediction of the plan's massive Greek rejection, the UN Secretariat was exercising unacceptable -politically and morally- pressure on the GCs. Thus, Russia's Deputy Ambassador to the UN, Gennady Gatilov, declared Moscow's conviction that the proposed resolution was attempting to influence unfairly the forthcoming referenda. When he vetoed it, he stated:30

"The [referenda] must take place freely, without any interference or pressure from outside".

Against the stubborn Western treatment of Cyprus as "a strategic piece of real estate", Moscow continued to defend the GCs' legal, political, and human rights that were being threatened anew. Once again, Russia's motivation was not exclusively "idealistic"; but this discussion aimed to show the pragmatic-idealist synthesis that proved sufficient for the Greek Cypriots. ${ }^{31}$

Throughout 1992-2012, the Nicosia-Moscow political dialogue was fruitful, as were the mutual visits by their presidents, their foreign ministers and other officials, from the parliamentary level to that of local government. Cypriot statesmen and other officials kept expressing Nicosia's "gratitude" to Moscow for its unceasing decades-long support. In turn, Russian officials and policy-makers did not tire to celebrate both mutual interests and the "spiritual affinities" and "spiritual bonds" between Russians and Greeks.

Self-explanatoryStatementsandDeclarations. Sergey Lavrov, interviewed by the Cyprus News Agency before his 2007 official trip to Nicosia, stated:

"At the basis of our traditionally friendly relations with the Republic of Cyprus lie strong historical and spiritual bonds $\{. .$.$\} . What brings us$ closer to each other is the common understanding of the necessity to be guided in international relations by universal principles and legal norms" 32 .

Mr Lavrov was clearly implying that Moscow shared the Republic's perpetual struggle to settle its existential problem, caused by Tur- key's invasion and the ongoing occupation, on the basis of international law and international ethics, as against Washington and London's realist fixations and Ankara's hegemonic bulimia. But analogous statements and declarations were regularly pronounced by Russian diplomats and other officials. For instance, in a 1998 interview with a TC newspaper, Ambassador Muradov boldly declared: $:^{33}$

"I want to tell the Turkish Cypriots openly: the recognition of an independent state, which was created in a military way with the help from the armed forces of a foreign country, regardless under what pretext this military action was done, is impossible and unacceptable in the modern world".

Similarly, Russian FM Spokesman, Andrey Nesterenko, declared during a September 2009 media briefing: ${ }^{34}$

"It goes without saying that Russia was never going to recognize the so-called 'Turkish Republic of Northern Cyprus'".

Two years later, confronting Turkey's gunboat diplomacy in Cyprus' EEZ, Ambassador Vyacheslav Shumskyi defended -as we sawthe Republic's rights according to the Law of the Sea, by stating that "this is totally in accordance with international law and with the EU regulations, so there is no doubt about that". ${ }^{35}$

The synthesis of idealistic statements and actions -primarily legal and ethical decisions and initiatives- with pragmatic or material interests continued during the Russophile years of President Tassos Papadopoulos (2003-2008). It was occurring even at the local administration level as, for instance, with the Nicosia-Moscow cooperation agreement, that was decided in February 2005 , "with a view to boosting and consolidating the good relations between the two capitals" 36 The cooperation agreement would provide for the exchange of community services in various fields, including construction of infrastructure projects, preservation of historic monuments in both towns and protection of the environment", through the "exchange of expertise, delegations and technology to achieve this goal" ${ }^{\prime 37}$.

\footnotetext{
${ }^{30}$ Ibid., p. 78.

${ }^{31}$ For Moscow's more "pragmatic" considerations, see Igor Torbakov's excellent essay, "UN Veto Sparks Debate on Russian Policy Aims", discussed in Russia-Cyprus Relations, pp. 79-80.

32 Ministry of Foreign Affairs of the Russian Federation, Information and Press Department, 26 December 2007, emphasis added.

33 Georgi Muradov, op.cit., p.171.

${ }^{34}$ See "Russia-Japan: Towards Reaching a Compromise", Russia Today website, 18 September 2009 (accessed 6 February 2012).

35 "Greece and Russia rally behind Cyprus", Cyprus Mail, 2 October 2011.

36 "Nicosia-Moscow set to sign cooperation agreement", Financial Mirror, Nicosia, 21 February 2005.

${ }^{37}$ Ibid.
} 
On the State level, characteristic were the results of then President Dimitris Christofias' November 2008 visit to Moscow. Presidents Dmitry Medvedev and Christofias signed a Joint Declaration entitled, "On Further Intensification of the Relations of Friendship and Comprehensive Cooperation between the Republic of Cyprus and the Russian Federation". ${ }^{38}$ Beyond political cooperation, the declaration covered many additional dimensions: from economic relations to cooperation of local authorities, continuing military-technical cooperation, collaboration in addressing "new threats and challenges" (such as terrorism and other criminal phenomena), ending with a long section on "cultural, religious andhumanitarian fields", expressed in typical "pragmatic idealist" language: "The Sides confirm that the development of bilateral cooperation in the humanitarian field has a strong foundation with regard to historic, cultural and religious closeness of the peoples of the two States" 39 .

Tourism and Investments. Russian tourism to Cyprus represents another major bridge between "pragmatism" and "idealism". Beyond enormous economic significance, it keeps demonstrating inter-people affinity and friendship. The number of Russian tourists visiting $\mathrm{Cy}$ prus was rising impressively: from 130,000 in 2000, they reached around 181,000 in 2008 and 224,000 arrivals in 2010, placing Russia among the island's top sources of holidaymakers ${ }^{40}$. The back then Cyprus Tourism Organization (CTO) representatives visiting Moscow in early 2012 expressed enthusiasm because Russian tourists were now expected to exceed 400,000, and because seven more Russian airports would be added for tourists to Cyprus, resulting in flights from a total of 16 cities $^{41}$.

One of Argyrios Pisiotis' observations about Russian tourism to Greece and Cyprus in the 1990s supports our analytic framework, since Russian tourism's revival applied also to "spiritual tourism". It was taking place along "the traditional routes which 19th century Russian pilgrims followed to Greece": that is, MoscowOdessa and then by ship to Constantinople, Thessaloniki, Mount Athos, Athens and Pales- tine. $^{42}$

Turning from the spiritual to the earthy, Cyprus' position among the top three States investing in Russia's economy should be emphasised $^{43}$. In 2001, Cyprus held the first place, representing $16,3 \%$ of total foreign investment income, followed by the US $(11,2 \%)$ and the UK $(10,9 \%)$. In August 2010, the total Cypriot cumulative investment in Russia amounted to USD52 billion, 38 billion of which consisting of foreign direct investment ${ }^{44}$.

These funds were mostly of Russian origin and going back to Russia using the extremely favourable terms of Cypriot legislation. However, among the other factors attracting Russian businessmen's money to Cyprus were the important opportunities it offered: (1) EU membership since 2004; (2) a regional and world business centre; (3) stability and safety; and (4) deeprooted mutually friendly attitudes.

On Mutually Friendly Attitudes. As regards to point (4), numerous enthusiastic judgments are regularly advanced. Ms Natalia Kardash, editor and publisher of the Limassol-founded weekly Vestnik Kipra, made a powerful anthropo-centric argument regarding Cyprus' attraction for both Russian businessmen and ordinary Russians. In a November 2010 conference on Russia-Cyprus relations, she replied to the question, "Why do Russians Choose Cyprus?" by arguing that, ${ }^{45}$

"... the most important reason is people. Cypriots like Russians. Russian people feel very comfortable here. There are many countries with good weather and similar business conditions. But Cyprus -I know it for sure- is the best country in Europe if you take into consideration how people treat Russians here... Many people say that in Cyprus they feel that they live a full life, they learn to enjoy every day".

According to Kardash's 2010 paper, around 50,000 Russians were then living in Cyprus. Around 46\%were visitors, earning money abroad and spending it in the Republic. The rest were counted as follows: Russian businessmen and their families, 26\%; employees of local and international companies, $13 \%$; wives of Cypriot citizens, $11 \%$; and Russian students welcomed at various Cypriot universities, $4 \%$. Finally, the following selected data from 2010 demonstrated

\footnotetext{
38 The Joint Declaration can be found at http://www.cyprus.gov.cy/MOI/pio/pio/nsf/All

${ }^{39}$ Ibid.

${ }^{40}$ Russia-Cyprus Relations, p.84.

41 Ibid.

${ }^{42}$ Argyrios Pisiotis, op.cit., p.421.

43 Russia-Cyprus Relations, p 81, n29.

${ }^{44}$ Ibid, p 82, for data provided by the All-Russian Consumer Market and Marketing Research Institute, 2010.

45 Natalia Kardash, "Russian Community in Cyprus: Advantages and Challenges", University of Nicosia Conference, 2 November 2010, p.1.
} 
the progressive incorporation of the Russian people in Cypriot life: Russian-speaking children number between 25,000-30,000; four Russian schools operate in the Republic; "there are more than 10 educational centres where children go in the afternoon"; and about 20 music and dancing schools use Russian as the main language ${ }^{46}$.

Following this celebration of bilateral bonding, I asked distinguished Russian analyst Dr Nadia Arbatova, if she would endorse my "pragmatic idealism" hypothesis. She replied with a confident "Yes!", having just concluded her own geopolitical analysis with the words, "Russia and Cyprus are natural allies!"47.

Analogous was Georgi Muradov's opinion, when interviewed in February 1999 by Russian Business and Trade Connections. Asked, "Why are Russia and Cyprus so close?" he first mentioned their well-developed treaties and legal agreements. He then added "good climate, political stability...favorable tax policy towards foreign companies and the sophisticated banking and business infrastructure. The geographical proximity of Russia and Cyprus also plays an important role, but for us it is more important that Cyprus is a traditionally friendly country, spiritually close to us and connected by strong historical ties" 48 .

Two Revealing Interviews. In 2010, Moscow's VIP-Premier magazine interviewed then President Dimitris Christofias and Ambassador Vyacheslav Shumsky ${ }^{49}$. The Cypriot president assured the magazine's editor that the closeness of the bilateral ties ' are based on the support and assistance your country provided and continues to provide to Cyprus. Our relations are underlain by common cultural and religious traditions, the commitment of our peoples to the ideas of peace, friendship and cooperation.". After noting the "firm and consistent support" that Moscow is giving Cyprus, he added that "Cyprus, in turn, as an equal member of the European Union and a good friend and partner of Russia, is working to strengthen relations between Russia and the European Union". As for tourism, Dimitris Christofias emphasised inter alia that its importance "cannot be reduced only to economic parameters" and that "Russian people visiting Cyprus discover right away that $\mathrm{Cy}$ prus could become their second home ${ }^{\prime \prime 50}$.

Turning to trade and economic cooperation, Dimitris Christofias stressed their continuous expansion and added: "The total volume of Russian investments in Cyprus in 2008 was EUR2 billion. These investments targeted mainly financial and economic services, real estate management, trade and repairs...Cyprian exports to Russia increased by 55\% in 2005-2008\{...\}The main products Cyprus exports to Russia are pharmaceuticals, citrus fruits and food in exchange for grain, wood, iron and fodder" 51 .

Ambassador Shumsky affirmed many of our "pragmatic idealist" theses. On the pragmatic side, he stated that the Republic has "preserved the status of one of the main investors in the Russian economy"; that Cyprus investments in Russia exceeded USD48 billion in the end of last year [2009]"; that "our country accounts for up to $80 \%$ of all foreign investments in Cyprus"; and that deposits of Russian individuals and legal entities in local banks remained considerable and comprised close to EUR14 billion" 52 .

As regards the "idealist" dimension, the Russian ambassador stated that "the last but not the least component of Cyprus' attractiveness are traditionally good relations between our countries and, what is more important, the people. Our compatriots are sure to feel them on the island"53. And when asked whether Russian tourists may face "difficulties" because of Cyprus' division, he replied that "we do not recommend our tourists to go to the northern part of the island", because "the so-called Turkish Republic of Northern Cyprus enjoys no international recognition (except for Turkey) and thus any entry into it through seaports and airports on its territory are treated as illegitimate by the Republic of Cyprus $\{. .$.$\} Therefore, we persistently recom-$ mend to the Russians to rest only in that part of the island where such control is in force" ${ }^{\prime 54}$.

Dmitry Medvedev in Cyprus. The pragmatic idealist synthesis was further confirmed in October 2010, through Dmitry Medvedev's Nicosia visit. The 15 different agreements signed on that

\footnotetext{
${ }^{46}$ Ibid.

${ }^{47}$ Nadia Arbatova, "Russia and Cyprus in the context of Regional and European Security", University of Nicosia Conference, 2 November 2010.

48 Georgi Muradov, op.cit., p.177, emphasis added.

${ }^{49}$ Interviews by editor Yevgeny Kosov, in Nicosia, VIP-Premier, Issue 05-06/2010.

${ }^{50}$ See Russia-Cyprus Relations, pp. 84-85 for more statements by Dimitris Christofias.

${ }^{51}$ Ibid.

52 Ibid, p 86.

${ }^{53}$ Ibid.

${ }^{54}$ Ibid. Ambassador Shumsky's interview was entitled, "Russia and Cyprus are linked by sincere friendship".
} 
occasion would, in Dmitry Medvedev's words, "create a solid foundation for the future business development". In fact, the new tax deal, preventing double taxation, could enhance the positive conditions already in place, so that Dmitry Medvedev could state that "Cyprus is perceived by our businessmen as a very convenient platform to make investments" 55 .

To be sure, Cypriots were eagerly awaiting confirmation that the ever-flourishing RussiaCyprus relations would remain unaffected by the ever-strengthening Turkey-Russia material embrace. Therefore, they welcomed President Medvedev's declaration that Russia's growing commercial and political relations with Turkey "do not pose a threat" to Cyprus ${ }^{56}$. Moreover,

"Our relations will remain just as friendly and mutually beneficial, and Russia will not change its position regarding the Cyprus question. This position is that Cyprus must be a single sovereign state with two communities\{...\}. We will continue to work towards this goal".

In 2011, when Turkey attempted again to intimidate Nicosia through verbal abuse and gunboat diplomacy, Ambassador Shumsky, condemned on legal grounds Ankara's bullying, as we already know. But the international and EU economic crisis had also reached $\mathrm{Cy}$ prus by mid-2011, rendering difficult the country's borrowing in international markets. When President Christofias requested assistance, Moscow responded immediately. It promised a generous loan of EUR2,5 billion at a favourable interest rate $(4,5 \% \mathrm{t})$. And during the CyprusRussia Friendship Association's 50th anniversary meeting in Nicosia, in November 2011, Georgi Muradov, representing the Russian Foreign Ministry, read out a message from Sergei Lavrov. Six words in this message constitute a paradigm of the "essence" of Russia-Cyprus relations: ${ }^{.7}$ "Russia is interested in close and fruitful cooperation with Cyprus on the basis of sincere friendship, mutual sympathy and common interests".

A Note on Mutual Benefits. To summarise the principal mutual benefits enjoyed by the two countries during 1992-2012, we may begin with Cyprus. The first most evident benefit was the strong sense of political security and diplomatic solidarity Moscow provided to the semioccupied Republic at the Security Council and bilaterally, through declarations, decisions, and actions. Second, Cyprus was grateful because Moscow's verbal actions affirming the legality of the Republic contradicted cynical AngloAmerican Realpolitik and Ankara's unending belligerence. Therefore, Moscow remained the principal reminder of Cyprus' traumatised sovereignty and territorial integrity, while fraudulent Western "creative initiatives" about the Cyprus problem, essentially aimed at exculpating Turkey. Third, the purely "pragmatic" benefits included Russia's remarkable economic platform in Cyprus, with serious banking and real estate investments, on top of Moscow's demonstration of readiness to help Cyprus face the international financial crisis. Fourth, Russian tourism was established as a provider of both valuable income and camaraderie. Finally, Cypriots were convinced that sincere friendship and mutual sympathy were bound to strengthen inter-state and inter-governmental political bonding resulting in spiraling mutual benefits.

Moscow, in turn, could treasure the political association with a grateful and faithful friend or "natural ally", enjoying Cyprus' pro-Russia voice in international fora, and primarily in Brussels, where one could even hear the devious assertion that "Cyprus is Russia's Trojan Horse". Second, Russia benefited by Cyprus' status as a top channel for massive investments. Indeed, by 2010, Cyprus' foreign direct investment to Russia reached USD61,961 million, followed by the Netherlands (USD40,383 million), Luxembourg (USD35,167 million), and Germany (USD27,825million) ${ }^{58}$ Third, Russia expanded via Cyprus its economic presence within the EU, while Russian investors acquired a strong foothold in Cypriot real estate, banking and other services, as illustrated by the two VIP-Premier interviews. Fourth, Cyprus became a safe, attractive and exciting tourist destination, for both general and "spiritual" Russian tourism. The relevant figures are quite impressive, especially when we compare the 148,740 Russian arrivals of 2009 to the 334,083 in 2011. Fifth, Russia's consistent treatment of Cyprus through respect for legal and ethical principles and values could strengthen Russian "soft power" and international prestige, especially during Russophobic times. Finally, other things being equal, Russia could count on manifold Cypriot sympathies in the perennially problematic Eastern Mediterranean.

\footnotetext{
55 "Medvedev Resolves Cyprus Taxation", Moscow Times, 8 October 2010.

56 Ibid.

57 "Russia Interested in Close Cooperation with Cyprus-Russian ForMin", ITAR-TASS News Agency, 9 November 2011.

${ }^{58}$ Quoted in Russia-Cyprus Relations, p.91.
} 


\section{3-2018: Towards a "Revisionist" Pragmatic Idealism?}

Dimitris Christofias became the only Cypriot president who did not seek reelection. His major weaknesses included his failure to perceive the coming economic crisis and the immense human tragedy of the July 2011 explosion at Mari, for which he was primarily blamed by the State-appointed investigator. ${ }^{59}$ As for his final relations with Moscow, Christofias himself complained that Vladimir Putin had avoided at the end even "to come to the phone". 60

Nikos Anastasiades won the February 2013 presidential election, supported by his rightwing DISY party, but asserting commitment to a balanced foreign policy towards both superpowers. Actually, whenever referring to Moscow's Cyprus record, Anastasiades would express the Cypriots' gratitude for sustained political and diplomatic support, economic cooperation, Russian tourism, and the strong religious and cultural bonds.

When the Eurogroup-imposed bail-in caused Cypriot panic, Nicosia sent immediately Finance Minister Michalis Sarris to Moscow on 20 March 2013. Although the entire affair remains rather foggy, Sarris' return with empty hands could be attributed to the preceding cooling in Putin-Christofias chemistry, the image of Cyprus' economy "under attack" from Brussels, and Moscow's unwillingness to risk an unnecessary falling out with the EU.

Ultimately, this traumatic EU-generated affair did not cause a Moscow-Nicosia crisis. In fact, there was a subsequent affirmation of the "special" relationship: first, only few Russian investors reportedly decided to leave the Island and those who stayed seemed to endorse the Russian proverb, "better an old friend than two new ones" . ${ }^{61}$ Second, Russian optimism was reportedly premised on Cyprus' high-quality expertise in legal, financial, logistical, banking and associated matters, entailing a positive economic future. Third, during his spring 2013 Moscow visit, then Minister of Defense, Fotis Fotiou, witnessed Moscow's desire to use Limassol port facilities for its military vessels cruising the Eastern Mediterranean. Indeed, such vessels were visiting the Limassol port during the ongoing
Syrian war. ${ }^{62}$ Fourth, in late summer 2013, Moscow lowered, as promised, the interest rate of the 2011 loan, generously extending its payment by some years. Finally, increasing numbers of Russian tourists reaffirmed the established "mutual sympathy" which also represented vital economic relief.

Anastasiades under Pressure. President Anastasiades, his Russophile rhetoric notwithstanding, occasionally appeared to be tilting towards Washington. But because Nicosia was subjected yet again to unconscionable Western pressures, it was hard to identify Anastasiades' authentic motivation. Still, the pressures concerned the "settlement" of the Cyprus problem, economic insecurity, and the promising Cypriot hydrocarbon deposits. In all these, the "idiosyncratic" -to put it euphemistically- American Ambassador, John M. Koenig, usurped the role of first fiddle. Thus, as keynote speaker during a September 2013 conference, extroverted Koenig advertised enthusiastically "the present ideal opportunity" to resolve the Cyprus problem, because of Anastasiades' electoral victory.

Anastasiades had been a passionate supporter of the Anglo-American Annan plan which the GCs rejected triumphantly in 2004 when Moscow exercised its famous veto. Now, he was ready to restart "bi-communal negotiations" along analogous lines, manifestly oblivious to the dark realities in Erdogan's Ankara and in Cyprus' regional geopolitics. But American and associated pressures became so asphyxiating that Anastasiades exploded on national television, on 15 January 2015. Accumulated stimuli for his angry eruption might have included his possible post facto recognition of Victoria Nuland's trap regarding the 11 February 2014 "Joint Declaration" with TC leader Eroglu that imposed a toxic framework for the "bi-communal negotiations"; John Koenig's 11 May 2014 (surrealistic) interview with Phileleftheros entitled, "You should trust Turkey more"; Joe Biden's advertised as "historic" visit that had turned into a historic disaster; Turkey's October 2014 crude violations of international legal norms in Cyprus' EEZ; and numerous other cases of deception and manipulation against Cyprus and its president, where a major role was performed by the widely discredited Nor-

\footnotetext{
${ }^{59}$ See Russia-Cyprus Relations, pp. 92-93, for this tragedy and its socio-political implications.

${ }^{60}$ See, for instance, "Complaints by Dimitris Christofias: Putin did not even come to the phone", Politis Online, 25 March 2013.

61 "'Better an old friend than two new ones' says the Russian Ambassador", Phileleftheros, 7 June 2014.

${ }^{62}$ See, for instance, "Piotr Velicky nuclear missile cruiser to make portcall to Limassaol", ITAR-TASS News Agency, 27 December 2013.
} 
wegian UNSG Special Advisor, Espen Barth Eide.

Thus, a furious Anastasiades asserted that he "was taken for granted" because of his 2004 support for the Annan plan; and that, since the Americans hesitated to disturb their relations with Turkey, they expected him to perform all concessions. Hence the title chosen by Phileleftheros the next day: "Anastasiades got angry: Shots against the UN Secretary General and the United States"63.

Meanwhile, whereas the US and the UK reacted to Turkey's new aggression by a lukewarm (pseudo-)condemnation, Moscow's strong denunciation emphasised:

"Unilateral actions and the show of force are unacceptable, because they are threatening to worsen the situation not only in Cypriot affairs but also in the broader region of the Eastern Mediterranean" ${ }^{64}$.

Anastasiades Goes to Moscow. Thereupon, Anastasiades turned to Russia. He declared anew the "special" character of the bilateral relations and fixed an official visit to Vladimir Putin. His February 2015 Moscow visit was quite successful, as Cypriot and Russian media attested. The latter chose such titles as "Russian warships allowed at ports of Cyprus for humanitarian purposes--president", "Cyprus opposes sanctions against Russia", and "Ever more politicians in Europe see negative results of sanctions - $\mathrm{Cy}$ prus' president" 65 .

The three-day visit gave the opportunity to the two presidents and Premier Medvedev, to Foreign Ministers Sergey Lavrov and Ioannis Kasoulides, and to Energy Minister George Lakkotrypis to reassert the relationship's excellent level and to enrich the long list of protocols and treaties with 11 new agreements ${ }^{66}$.

Costas Venizelos, a leading Cypriot journalist and author, commented on the visit's rich results and promising implications. He noted that "Moscow perceived positively Cyprus' axis with Egypt, as well as the one with Israel, and favours the cooperation of the three States of the region"; that Moscow's interest in energy issues is oriented towards investing in shares from companies already active in Cyprus' EEZ; that Moscow's primary interest appears to be geostrategic, with energy issues operating in a supporting role, something that fits Nicosia's own calculations and desires. Venizelos also recorded Anastasiades' request that President Putin may talk directly to Erdogan about the Cyprus issue. As for the military agreement, Costas Venizelos clarified that the Russian navy's right to use the Limassol port could not harm Cyprus' relations with its other partners ${ }^{67}$.

Russian Popularity in Cyprus. As regards the GCs' relevant sentiments, they kept favoring the ongoing level of bilateral Moscow-Nicosia relations and wished for even stronger ties. Admittedly, formal opinion research on these relations has been sporadic. Considering, however, the principal "authors" of Cyprus' vicissitudes -i.e. Washington, London, Ankara and increasingly the UN Secretariat- one could discern that Russia was bound to be favored by most GCs, appreciating primarily its being Cyprus' most powerful political and diplomatic counterweight. This intuition was simultaneously supported by the explicit appeals to Moscow's positive role by analysts, opinion makers and the "Centrist" political elites. Thus, anecdotal evidence had crystallized that GCs' affection and hopes are certainly oriented towards Moscow ${ }^{68}$.

This perception was verified in a 2015 opinion research. First, referring to a poll conducted in mid-December 2015 by Nicosia daily Simerini, the Cyprus Mail noted, inter alia:69 "Almost three out of four Cypriots would welcome the provision of military facilities to Russia by Cyprus $\{. .$.$\} .Over half of those polled island-wide$ on 16-17 December said the government should seek closer ties with Moscow." In addition, "Three out five said they would feel safer if there was a Russian military presence on the island\{...\}.. Seven out of ten Cypriots were open to offering military facilities to Russian forces fighting against terrorism, with $37 \%$ going as far as saying Cyprus should give them a base $\mathrm{e}^{70}$.

\footnotetext{
63 Phileleftheros, 16 January 2015.

${ }^{64}$ Costas Venizelos, "Russian 'canons' against Turkey", Phileleftheros, 10 October 2014.

${ }^{65}$ For details, see Russia-Cyprus Relations, p.163.

66 Ministry of Foreign Affairs of the Republic of Cyprus, "The Republic of Cyprus and the Russian Federation signed a number of Agreements and Memoranda of Understanding", 25 February 2015.

${ }^{67}$ Costas Venizelos, "Selling natural gas creates new conditions: the Cyprus-Egypt agreement creates fait accompli", Phileleftheros, 22 February 2015.

68 The conviction that Russia is favored by most Greek Cypriots was shared by Aris Petasis and William Mallinson in "Without Russia it's only Hobson's choice for Cyprus", Defend Democracy Press, 10 February 2017.

${ }^{69}$ Jean Christou, "Poll: majority would favor granting military facilities to Russia", cyprus-mail.com, 20 December 2015.

70 Ibid., emphases added.
} 
Similarly, an ongoing multidimensional project, subtitled, "Ideas for a new Security Architecture", ${ }^{71}$ had been interviewing Greek Cypriots and Turkish Cypriots on possible Cyprus "futures". Most revealing are the answers to "Potential Guarantor States". Among the Turkish Cypriots, 69\% responded that Turkey would be "satisfactory or desirable", placing it on top, while the least "satisfactory or desirable" was Russia, supported by only $10 \%$. Russia, moreover, was voted "Unacceptable" by $68 \%$ of the responding TCs.

Contrariwise, Russia was favored by $53 \%$ of the Greek Cypriot respondents, who placed it on top of all alternatives. Not surprisingly, Turkey was the most "unacceptable" (84\%), preceded by the UK $(70 \%)$ and the US (51\%). In addition, while Russia was "unacceptable" to only $32 \%$ of the GCs, $16 \%$ of them found Russia "tolerable". Therefore, adding the latter to the $53 \%$ of "satisfactory or desirable" reaches a total of $69 \%$, compared to a mere $49 \%$ for the US and 30\% for the UK.

Anastasiades' Moscow visit of 2015 was followed by two more years of balanced pragmatic idealism: constant bilateral confirmations of the bilateral status -common interests, sincere friendship, and historical-cultural bonds - were accompanied by positive developments in diplomacy and politics, economy and trade, culture and tourism and by successful high-level visits. Cyprus was even attempting to reduce EU Russophobia, something appreciated by Moscow and its Nicosia embassy. Ambassador Osadchiy kept reiterating Russia's willingness to help resolve fairly the country's problem, "if asked". Anastasiades' next trip to Moscow with a business agenda, in October 2017, also proved productive. The Russian festivals in Limassol were attended by enthusiastic bi-national crowds. A new political party - called "I the Citizen," was created by Russians living on the Island. And a new, magnificent, Russian Orthodox Church was inaugurated near Nicosia.

Intensified Turkish Hostility. Simultaneously, given Cyprus' existential problem, Nicosia was pursuing energetically a multilateral foreign policy, by deepening its trilateral relations with
Greece and Egypt as well as Israel and Greece. And while the numerous official documents, signed in Nicosia, Cairo, Tel Aviv and Athens, insisted on their aiming at regional peace, security, and energy collaboration - "without any hostility against other parties"- it was abundantly clear that such multiple cooperation was fueled by Turkey's unending hostility contra omnes.

Demonstrably, Turkey has occupied central place in Nicosia-Moscow relations. We have seen that, since the 1960s, Cyprus has relied mainly on Russia to cope with Ankara's threats and provocations and to overcome obstacles to a fair Cyprus settlement. Therefore, Moscow's responses to Turkey's recent behavior are essential to assessing current Cyprus-Russia relations.

Stuck in the Syrian minefield, with serious domestic problems, and isolated in the Eastern Mediterranean, Erdogan keeps escalating both his offensive rhetoric against Cyprus, Greece, Israel and Egypt, as well as aggressive actions in the Aegean Sea and the Cypriot EEZ. I have concluded that Turkey's geopolitical troublemaking emanates primarily from Erdogan's sui generis "Machiavellian rationality" and his geopolitical megalomania. ${ }^{72}$ Nicosia's recent contracts with energy colossi such as ExxonMobil, Qatar Petroleum, TOTAL, ENI, and Kogas, have infuriated Ankara. Hence Turkey has been bullying its neighbours, challenging the energy companies, and threatening daily to use military force under preposterous rationalisations, such as that its own EEZ extends south of Cyprus (!); that it "rejects" Cyprus' EEZ delineation agreements with Israel and Egypt; and that it represents the TCs' (allegedly) "violated rights"! !3

Now considering that Ahmet Davutoglu's "guideline" -"No problems with our neighbors"- has been obliterated; that Erdogan's regional ambitions have included illegal and lethal activities in Syria and Iraq; and given the foolhardy November 2015 conflict with Moscow and the protracted Machiavellian playing the US against Russia - for at least these reasons we have been witnessing tempestuous geopolitics, affecting Cyprus directly and dramatically.

${ }^{71}$ See The Security Dialogue Initiative for Cyprus, commissioned by the Berghoff Foundation, Seed, and Interpeace, and written by Dr Giorgos Kentas and Dr Ilke Dagli. The respondents exceeded 3000 persons from both Communities. See www.newsincyprus.com/news/50188/research-project-on-security.

72 Costas Melakopides, "How Rational is President Erdogan's Policy against Cyprus and Greece? A Case Study", Russian International Affairs Council (RIAC), Moscow, 8 May 2018, http://russiancouncil.ru/en/analytics-and-comments/ columns/military-and-security/howrational...

${ }^{73}$ For Erdogan's propagandistic devices, including his favorite strepsodikia (chicanery), see my "Brief Remarks on President R. T. Erdogan and His Allies' Methodical Use of Logical Fallacies", RUDN Journal of Political Science, Vo. 20, No3, 2018, http://journals.rudn.ru/political-science/article/view/19639. 
And since Erdogan's unending victimisation of Cyprus demonstrates contempt for International Ethics and International Law, Cyprus has been expecting effective international measures against Ankara.

Enter Disagreements and Complaints. Greek Cypriots have apparently expected Moscow's explicit solidarity and support. Moscow, however, may complain that Cyprus' newly expanding relations with Washington violate Nicosia's professed "symmetrical" treatment of the superpowers. A potential vicious-causal-cycle might thus arise, especially because problematic actions cohabit with contradictory statements. For instance, in early 2019, Foreign Minster Nikos Christodoulides called Cyprus-Russia relations "excellent". ${ }^{74}$ To my question, "Can we call them excellent after Ms Zacharova's December 2018 'warning'?" the energetic and charismatic Cypriot FM replied: "'Excellent' does not mean we cannot have disagreements". But one day later, talking to high school students, he contradicted the pragmatic idealist bilateral tradition through the quintessential Realpolitik assertion: "... in Foreign Policy only interests exist"75.

In early 2019, a perceptible fluidity in recent Russia-Cyprus relations, caused by the regional geopolitical Gordian knot, arose primarily as follows: (1) Washington insinuated a strategic interest in Cyprus; (2) Nicosia appeared willing, potentially upsetting the traditional "symmetry"; (3) Moscow's rapprochement with Ankara is deepening; and (4) Cyprus has emerged as a significant locus of renewed Eastern Mediterranean geopolitical antagonism.

1. Washington has long been calling USCyprus relations "strategic". But this adjective had been hyperbolic and euphemistic. Things began to change, however, by two sets of developments. The first followed the dramatic crisis caused by the notorious shooting down of the Russian Sukhoi Su-24M attack aircraft on 24 November 2015. After Erdogan's "apology" to Vladimir Putin and, considering Moscow's perceived aspiration to break Turkey's ties to Washington and NATO, but also in view of Erdogan's exploitation of the two superpowers' eagerness to woo his country, there emerged the ongoing uncertainties in the Ankara-MoscowWashington triangle. And second, Erdogan's megalomaniacal regional expansion has included his preparedness to threaten even the international energy companies in tandem with his "games" regarding the Russian S-400 versus the Patriot and the F-35 aircraft. Thus, Washington's patience is frequently reportedly as exhausted since Ankara's reliability as a "NATO ally" has been thoroughly undermined. By 2018, Washington's fatigue with Erdogan's Turkey led to the effective endorsement of Nicosia's tripartite quasi-alliances with Israel, Greece and Egypt; and in view of ExxonMobil's persistent explorations in the Cypriot EEZ, a perceptible warming of US-Cyprus relations was effected by verbal and nonverbal actions.

2. Cypriot insistence on the "symmetry" assertion raised doubts in Russia. Moscow has also been annoyed by European and US campaigns against Russian depositors in Cyprus. Maria Zacharova's 5 December 2018 severe denunciation of Cyprus' suspected "militarisation" by Washington contradicted traditional assurances of idyllic bilateral relations: ${ }^{76}$

The further militarisation of the island and its involvement in the implementation of American and NATO plans will inevitably lead to dangerous and destabilizing consequences for Cyprus itself. Moscow cannot but take into consideration the anti-Russian background of these schemes. We will have to take response measures in case of their implementation.

(Immediately, the Cypriot FM phoned Sergei Lavrov; the two men managed to block any escalation and agreed to meet shortly in Moscow.)

3. The Putin-Erdogan rapprochement cannot be doubted, (doubts, however, may exist about its duration.) When they had concentrated on trade, tourism and mutual investments, I had argued that their "material embrace" could co-habit with the far deeper and "special" RussiaCyprus bonds ${ }^{77}$. Currently, however, MoscowAnkara relations are developing dramatically with unpredictable geostrategic implications.

4. The ongoing exploration for hydrocarbon deposits has increased Cyprus' geostrategic attractiveness and reaffirmed its status as an unsinkable aircraft carrier. But there are also "geoeconomic" cards in the Cypriot geopolitical game. Uppsala University's Dr Igor Torbakov, after noting the long and "multifaceted Russian influence" in Cyprus, and "the importance of

\footnotetext{
${ }^{74}$ Nikos Christodoulides, Lecture on Cypriot Foreign Policy, organized by think tank ERPIC, Hilton Hotel, Nicosia, 23 January 2019.

75 "The students ask, the Cypriot FM answers: In foreign policy there are only interests", Hellas Journal, 25 January 2019.

76 "Russia vows tit-for-tat response to US' military build-up in Cyprus", TASS Russian News Agency, December 5, 2018, www.tass.com/politics/1034376.

77 Costas Melakopides, "On the 'Special' Nature of the Russia-Cyprus Relationship", RIAC Website, 20 June 2017.
} 
the Russian factor for Cyprus' economic wellbeing", commented:

Yet precisely this factor made Cyprus extremely vulnerable vis-à-vis the demands of US authorities, now pressuring Cypriot banks to clean up their act and apply stricter measures against "Russian money laundering". So Cyprus finds itself stuck between a rock and a hard place: its bankers hate to cut their best clients yet they can ill afford to antagonize the US as they heavily depend on US corresponding banks in all their dollar transactions. I guess Bank of $\mathrm{Cy}-$ prus CEO John Hourican put it quite nicely last October in an interview with the Wall Street Journal. "The US and Russia are in a kind of economic war and you fight those wars where the two sides meet", he said. "They meet in Cyprus"78.

Dr. Torbakov, who called Cyprus' current situation "unenviable", added that ' it is seemingly a typical predicament of a small country that performs a delicate balancing act maneuvering between the regional interests of the great powers". Moreover, "the Kremlin appears to have become suspicious of Cyprus' readiness to shift strategically towards its arch-enemies NATO and Washington. This suspicion seemed to have prompted Russian MFA to issue the infamous warning to Cyprus last December. ${ }^{79}$

To assess current suspicions and/or actual complaints of the two capitals, we note that Moscow finds problematic (a) Nicosia's upsetting the traditional "symmetry" through a penchant towards a stronger engagement with Washington; and (b) Nicosia's inability to resist Western demands to confront alleged Russian money laundering. For Cyprus, three major issues are disheartening: (a) Moscow's commitment to build the Akkuyu nuclear power plant just across Cyprus' northern shores; (b) its decision to sell Turkey the S-400 system; and (c) Moscow's abstention from a decisive condemnation of Ankara's blatant violation of international law in Cyprus' EEZ.

Moscow's disappointment regarding (a) appears reasonable enough. Nicosia, however, might argue that what is now occurring is rather a "defensive strategic flirtation", resulting from Moscow's multiple bonding with Erdogan's Turkey and its current "neutrality" towards Turkey's provocations, and aiming to protect the energy giants operating in its EEZ. Russia's second complaint is arguably also inflated, con- sidering the ruthless measures that the "West" can apply against small Cyprus, such as the notorious bail-in imposed in 2013 by the Eurogroup.

Cyprus' three complaints appear more defensible. Since the Akkuyu area is manifestly seismogenic, Cypriot and Turkish ecologists consider building such a power plant extremely risky and even terrifying. Next, the fears related to Ankara's purchasing the S-400 missiles are also fully rational, if only because of Erdogan's "Machiavellian rationality". As for Moscow's current "toleration" of Erdogan's aggression in Cyprus' EEZ, Cypriots juxtapose it to Russia's powerful pro-Cyprus responses in 2011 and 2014.

Reaffirming Pragmatic Idealism. And yet, no evaluation of recent Moscow-Nicosia relations can ignore some parallel signals that neither of them wishes to endanger their "special" relationship. Thus, Nikos Christodoulides' April 2018 Moscow meeting with Sergei Lavrov was marked by positive promises and implications. In Nicosia, Ambassador Osadchiy regularly reiterates Moscow's entrenched support for Cyprus. In fact, he also contributed skillfully to defusing the December 2018 "crisis". ${ }^{80}$ And Russia's UN Ambassador, Mr Nebenzia, during the 30 January 2019 Security Council discussion about the UNFICYP's future, supported Cyprus' wishes versus renewed Anglo-American intrigues ${ }^{81}$.

Turning again to Dr Torbakov for a concluding assessment, I received the following sophisticated response:

'In general, I would agree with your overall conclusion. Indeed, these days «pragmatism» and «idealism» - two pillars of a «special» Russia-Cyprus relationship - appear to be out of balance, with the former seemingly eclipsing the latter. But it is also true that both sides would rather prefer to return to the status quo ante, whereby «pragmatism» and «idealism» reinforce each other instead of working at cross purposes. My little piece of advice to the Russian side would be as follows: in its relations with Nicosia, Moscow has to absolutely eschew overbearing and heavy-handed behaviour - a natural predilection of a great power with a long imperial pedigree. Cyprus is a small but proud nation; in the past, it was part of the Ottoman realm and then a British colony. The last thing the Cypriots want is a sense of being owned by a new master who thinks he has the right to lord it over them ${ }^{82}$.

\footnotetext{
${ }^{78}$ Igor Torbakov, Correspondence with the author, 18 February 2019.

${ }^{79}$ Ibid.

80 "Russia Ambassador says recent spat involves US not Cyprus", Cyprus Mail, 10 December 2018.

81 United Nations, Security Council 8453 $3^{\text {rd }}$ meeting, 30 January 2019.

82 Correspondence with the author, 21 February 2019.
} 
On 22 February 2019, Nikos Christodoulides paid his official visit to Sergey Lavrov. After the talks, the Cypriot FM stated that "the bilateral relations are at a very satisfactory level"; that they agreed with Mr Lavrov "to work together, in concrete actions, for the further development of these relations in a number of subjects of common interest". Regarding the Cyprus problem, he expressed "the appreciation of the Republic of Cyprus for the diachronic stance of the Russian Federation, especially in the framework of the UN Security Council, [its] clear position on the abolition of the anachronistic system of guarantees of 1960, as well as the need for the unobstructed continuation of the UNFICYP's presence, for as long as the present unacceptable state of affairs continues" 83 .

Intriguingly, Mr Lavrov's own statements sounded more positive and "warmer". First, he employed his unmistakably "pragmatic idealist" formulation: "Cyprus is Russia's important and long-time partner in Europe. Our cooperation hinges on long-standing bonds of friendship and mutual sympathy, the spiritual and cultural affinity of our nations and serves to enhance security and stability in the East Mediterranean region and on the entire European continent" 84 .

He then added that "We are satisfied to note positive trends in all areas of bilateral cooperation $\{. .\} .$.$" And by sharing explicitly Nicosia's re-$ cent proposals regarding the Cyprus problem, he implicitly condemned Ankara's arrogance: "the current system of the island's external security guarantees no longer meets modern realities and the Republic's current international status. We firmly believe that the UN Security Council's guarantees should become the most effective method for maintaining the security, sovereignty and territorial integrity of a united Cyprus' $^{\prime 85}$.

This February 2019 Moscow meeting justified the perception that Mr Lavrov had transcended recent "misunderstandings" easier than his Cypriot counterpart. Hence, "my little piece of advice" to Nicosia would be that, in its relations with Russia, it is rationally imperative to eschew simple Realpolitik aphorisms and analogous stances. Presently, "pragmatism" is more elevated in Nicosia's foreign policy than "pragmatic idealism". Happily, Moscow's version of Cyprus-related "idealism" remains alive and well, promising the further cultivation of the principled and mutually beneficial "pragmatic idealist" synthesis in Russia-Cyprus relations. Nicosia, remembering what it owes to Moscow, and how it has been victimised repeatedly by its Western "strategic partners", should respect the pragmatic-idealist balance of previous decades, for reasons of rationality, consistency, and decency.

\section{Epilogue}

The above analysis was completed by midMay 2019. Given, however, the escalating struggles of regional geopolitics and the long anticipated G-20 Conference in Osaka, Japan, I postponed the submission of the present study.

Meanwhile, on the positive side, the RussianCypriot dialogue remained cordial on the local level, as demonstrated by the warm statements exchanged during the Russian Federation's National Day celebration by President Anastasiades and Ambassador Osadchiy ${ }^{86}$.

On the other hand, Washington's interest in Cypriot affairs took more controversial forms. First, Senators Robert Menendes and Marco Rubio prepared legislation -recently endorsed by the Senate Foreign Relations Committeeproposing the promotion of US relations with Cyprus, Israel and Greece. However, at the last moment, the legislation demanded that $\mathrm{Cy}$ prus should deny the Russian Navy the use of its ports! Immediately, President Anastasiades condemned this demand, arguing that it would curtail Cypriot sovereignty. The condemnation was also shared by government officials and by Centrist political leaders ${ }^{87}$.

In addition, a 29 June op-ed article by retired Vice-Admiral Constantine Fitiris clearly condemned the emerging development because it would render Cyprus a "consumable pawn" in American geostrategic games: ${ }^{88}$

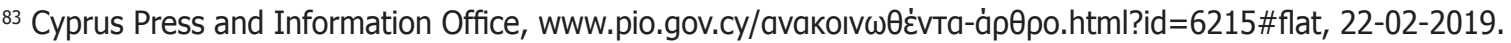

${ }^{84}$ Ministry of Foreign Affairs of the Russian Federation, "Foreign Minister Sergey Lavrov's remarks at a joint news conference following talks with Minister of Foreign Affairs of the Republic of Cyprus Nikos Christodoulides, Moscow [...], 22-02-2019.

85 Ibid.

${ }^{86}$ See "Russia closely monitoring Turkey's actions, says ambassador", www.cyprus-mail.com/2019/06/08/russiaclosely-monitoring-turkeys-actions-says-=ambassador/

${ }^{87}$ Cypriot Minister of Defense, Savvas Angelides, fully agreed on 1 July 2019 during his morning television interview with the Cyprus Broadcasting Corporation (RIK).

${ }^{88}$ Constantine Fitiris, "US-Cyprus Relations: Bitter Truths", 29 June 2019, sigmalive.com/news/opinions/_ sigmalive/575704/sxeseis-hpa-kypriakis-dimokratias-...
} 
So, what is the solution? We should refuse to "play" in this chessboard because, in the fluid situation in the Eastern Mediterranean, our cost will be far greater than our benefit. If we hurt our relations with Russia we will obviously lose its support in the Security Council and if, simultaneously, the US warm up again their relations with Turkey (which is quite likely!) then the situation will be very dangerous for the Republic of Cyprus. We should not forget that, of the permanent members at the Security Council, we always had the support of France, China and Russia (whereas) the UK and the US usually abstain from resolutions favorable to us.

While welcoming this position (which fully coincides with our own conclusions), I wish to submit the following final observations, three days after the Osaka Conference.

The Trump-Erdogan meeting yielded no clear answers on the unprecedented US-Turkey crisis. In fact, respectable observers expressed additional anxieties primarily because of Tayyip Erdogan's mind-boggling haughtiness and Donald Trump's "delirium". ${ }^{89}$ Specifically, Erdogan declared both that the S-400 system will definitely be deployed in July and that, nonetheless, "Trump is not going to apply sanctions to Turkey.

As for Donald Trump, he astonished everyone by his seemingly inexplicable cordiality and even affection towards Erdogan and his delegation and by the inherent contradictions in his uncontainable statements. Space only allows to record that he recognised "the mess of US-Turkey relations"; he accused -falsely! - President Obama of refusing to sell the Patriots to Turkey; therefore, he (essentially) held Obama responsible for Erdogan's resort to the S-400 system; he, therefore, attempted to absolve Erdogan of any responsibility, even though, for months, Washington had been warning Erdogan against the missiles' acquisition and threatening him with the sanctions already passed by the US Congress. Here are President Trump's initial and final words in response to the question on sanctions for Turkey: $:^{90}$

Okay, so Turkey is an interesting case-because there's another one, Jim, that I get along with very well, and he is a tough cookie, okay? Right? President
Erdogan. He is tough, but I get along with him. And maybe that's a bad thing, but I think it's a really good thing. Because, frankly, he wanted to wipe out-he has a big problem with the Kurds, as everyone knows. And he had a 65,000-man army at the border, and he was going to wipe out the Kurds, who helped us with ISIS. We took out the caliphate. We have 100 percent of the caliphate...

...So it is a mess. It is a mess. And honestly, it isnot really Erdogan's fault. So we have breaking news. 'Donald Trump loves Turkey. He loves Turkey. Donald Trump is on the side of Turkey instead of the United...' No, I'm not.

First, President Trump appeared once again as a happy protagonist in an international act of the Theatre of the Absurd. His incoherence and quasi-surrealistic answers to a concrete and very serious question justify the hypothesis that the US President is not fully rational and may lend further credence to author Michael Wolff's claim that "the president is 'functionally a madman' and those who have spent most time with him describe him as 'vile and ludicrous'".$^{91}$

Second, most probably, Donald Trump's attempted defense (?) of Erdogan will be undermined by his cabinet, precisely as in the recent case of the "promised withdrawal of US troops from Syria. In any case, the US Congress has already decided that, should the S-400 arrive in Turkey, it will be subjected to heavy sanctions.

Third, it remains extremely hard to predict President Erdogan's future decisions vis-à-vis Cyprus (and Greece), in spite of the sanctions also threatened by the European Union for his international law violations in the Eastern Mediterranean and the Aegean Sea, and despite the sorry state of Turkey's economy today.

Finally, while Greece keeps strengthening its deterrence (having, at long last, abandoned the naivety of appeasement), Cyprus keeps mobilising its own defense mechanisms, that is, primarily diplomatic and legal means. It follows, therefore, that the Russian Federation will remain a powerful "gigantic counterweight" for Hellenism, especially at "interesting times" like the present ones.

But here, this "historical" account should end, before it becomes futurological.

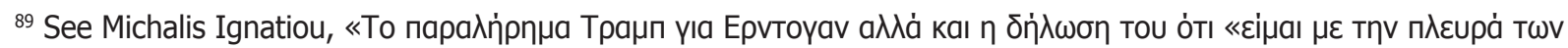
НПА», 30 June 2019, www.hellasjournal.com/2019/06/to-paralirima-tramp-gia-erntogan-alla-

90 Ibid.

${ }^{91}$ See "Michael Wolff: 'Vile And Ludicrous' President Trump Is 'Functionally A Madman", www.realclearpolitics.com/ video/2019/06/03/michael_wolff_vile_and_ludicrous_president...
} 


\section{ОТНОШЕНИЯ МОСКВЫ И КИПРА С 1950-Х ГОДОВ: ПРИНЦИПИАЛЬНЫЕ ОСОБЕННОСТИ.}

Учитывая неизбежные разногласия, вытекающие из политических, идеологических, психологических склонностей и доминирующих идей, невозможно отрииать, что в течение всего времени после Второй мировой войны Москва проявляла дружбу, солидарность и многоплановую поддержку по отношению к Кипру и грекамкиприотам, составляющим подавляющее большинство его населения. Отсюда постоянная и глубокая благодарность со стороны кипрских политических элит, политиков, формирующих политическую повестку, и широких слоёв гражданского общества. Выделяются три основных источника этих «особых отночений»: вопервых, Москва, следуя своим собственным геополитическим целям, одновременно предложила Кипру защиту от англо-американских ошибок, грехов и даже преступлений; во-bторых, $b$ отмичие от исключительно эгоистической стра-

\section{Ключевые слова:}

холодная война, отношения Москвы и Кипра, геополитический интерес тегии и тактики Запада $b$ отнотении Кипра, двусторонние связи между Москвой и Кипром $b$ иелом основаны на синтезе взаимных интересов, общих норм и общих иенностей; и b-третьих, до самого недавнего времени Москва оказывала Республике Кипр постоянную поддержку $b$ отночении угроз и провокаций Турции. За исключением последнего измерения, которое рассмотривается ближе к кониу этого эссе, мои основные тезисы и подтверждающие эмпирические данные об уникальных российско-кипрских отномениях впервые были разработаны $b$ моей книге 2016 года «Отномения между Россиеи и Кипром».

Костас Мелакопидес, доцент кафедры международных отношений (в отставке), Университет Кипра.

Keywords:

Cold War, Moscow-Cyprus Relations, geopolitical interest 